\title{
Zemřel MUDr. Pavel Jerie - skvělý lékař, internista a kardiolog
}

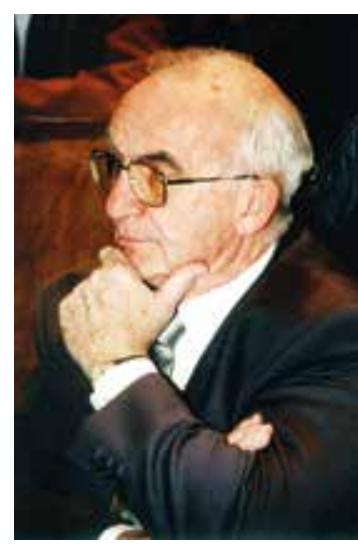

Zemřel skvělý lékař, internista, kardiolog a klinický farmakolog MUDr. Pavel Jerie, který patřil do generace lékařů, kteří zakládali $v$ 60. letech odborné ambulance - on konkrétně kardiologickou ambulanci v Ústí nad Labem. Pod tlakem událostí roku 1968 musel (jako mnoho ostatních) emigrovat. Připomeňme si životní dráhu tohoto vynikajícího lékaře.

MUDr. Pavel Jerie se narodil 9. prosince 1927 v Praze. Lékařskou fakultu Karlovy univerzity studoval v Praze, promoval 19. prosince 1951. Již během lékařských studií pracoval v letech 19471951 v Biologickém ústavu Karlovy univerzity. Po promoci v letech 1952-1956 pracoval na Interním oddělení nemocnice $v$ Mostě $a$ záhy se rozhodl věnovat kardiologii. V roce 1955 složil atestaci z vnitřního lékařství I. stupně. Od roku 1956 do roku 1969 pracoval na Interním oddělení Krajské nemocnice v Ústí nad Labem. V letech 1957, 1961 a 1965 absolvoval stáže v Ústavu chorob oběhu krevního. V lednu 1958 úspěšně složil atestaci z kardiologie a cévních chorob u obávané trojice zkoušejících profesorů Klementa Webera, Jana Broda a Františka Herlese.

Dr. Pavel Jerie se stal jedním z prvních krajských kardiologů, a to v Severočeském kraji, v Ústí nad Labem. $\mathrm{V}$ tomto městě by jistě dál působil, kdyby nedošlo k osudné okupaci Československa v srpnu roku 1968. Pavel Jerie se aktivně angažoval v Pražském jaru a stal se členem předsednictva nové Lékařské společnosti založené v Brně v červnu roku 1968, jejímž členem byl také MUDr. F. Kriegel. Ze všech jeho prací té doby jmenujme především učebnici Kardiologie praktického lékaře (obr), která se těšila velké oblibě nejen u praktických lékařů, ale sloužila též pro všechny lékaře, kteří se připravovali na atestaci z interny. Tato publikace se dočkala i 2. doplněného vydání. V letech 1962-1968 také přednášel kardiologii na pobočce IPVZ (tehdy ÚDL) v Krajské nemocnici v Ústí nad Labem.

Po srpnových událostech emigroval se svou rodinou do Švýcarska a po řadě obtíží zakotvil v Basileji, v klinickém výzkumném oddělení farmaceutické společnosti Sandoz (nyní součást společnosti Novartis). Pavel Jerie aktivně vedl v Basileji některé studie s novými antihypertenzivy, především s centrálně působícím antihypertenzivem guanfacinem, o němž přednášel např. na 8. světovém kardiologickém kongresu v Tokiu. Klinické zkušenosti s guanfacinem pak uveřejnil v British Jour- nal of Clinical Pharmacology. V roce 1989 mu bylo uděleno ocenění Distinguished Leadership Award za zásluhy o vývoj léků proti hypertenzi.

Bylo zásluhou Pavla Jerieho, že se v Československu ralizovala první prospektivní dvojitě slepá, klinická studie o vlivu inhibitoru ACE spiraprilu v léčbě chronického srdečního selhání. Domlouvali jsme tu studii tehdy s Pavlem spolu dohromady. Studie se pak zúčastnilo 17 fakultních pracovišt' z České a Slovenské republiky, od Plzně až po Košice. Rád a jistě i ostatní účastníci studie, které se účastnila všechna česká a slovenská kardiologicky orientovaná pracoviště, vzpomínáme na schůzky řešitelů studie konané v Praze, které jsme spolu s Pavlem vedli. Pavel Jerie tak stál u počátků léčby chronického srdečního selhání inhibitory ACE.

Pavel Jerie se po listopadu roku 1989 často objevoval na kongresech České kardiologické společnosti a také České společnosti pro hypertenzi. Rád diskutoval a jeho přispěvky znamenaly vždy obohacení diskuse. Četl pravidelně české časopisy, včetně Vnitřního lékařství.

Pavel Jerie byl také jmenován čestným členem České kardiologické společnosti a České společnosti pro hypertenzi. V posledních letech se stal také členem redakční rady Časopisu lékařů českých. Zůstal tak "jednou nohou“ doma a jsme tomu rádi.

Dr. Pavel Jerie zemřel 29. října 2018 ve Švýcarsku ve věku nedožitých 91 let. Mnozí z nás jsou Pavlovi vděčni za mnohé poučení nejen o kardiologii, výzkumu léků, ale hlavně za jeho přátelství. Milý Pavle, za všechny kardiology a internisty od Ústí po Brno, Prahu a Košice a další města nevyjímajíce, nikdy nezapomeneme, co jsi pro československou kardiologii a internu vykonal.

Čest Tvé památce!

Jiři Vítovec a Michal Fejfuša

\section{prof. MUDr. Jiří Vítovec, CSc. هiri.vitovec@fnusa.cz}

I. interní kardio-angiologická klinika LF MU a FN u sv. Anny, Brno iweb3.fnusa.cz

\section{Vybrané publikace MUDr. Pavla Jerieho}

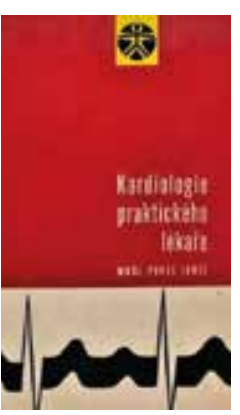

1. Jerie P. Kardiologie praktického lékaře. SNZL: Praha 1964; 1968 (2nd ed). 2. Jerie P. Pro koho je medicína? Světem za lepšími léky. Academia: Praha 2009. Edice Pamět' 21. ISBN 978-80-200-1710-9.

3. Jerie P. Clinical experience with guanfacine in long-term treatment of hypertension. Part I. Efficacy and dosage. Br J Clin Pharmacol 1980; 10(Suppl 1): 37S-47S. 
4. Jerie P. Clinical experience with guanfacine in long-term treatment of hypertension. Part II. Adverse reactions to guanfacine. Br J Clin Pharmacol 1980; 10(Suppl 1): 157S-164S.

5. Jerie P. Long-term evaluation of therapeutic efficacy of guanfacine. Am J Cardiol 1986; 57(9): 55E-59E.
6. Jerie $P$, Kremer HJ. RENPRESS'R',SANDOPRIL'R' (SPIRAPRIL/TI 211-950). Summary of Chemical, Pharmacological and Clinical Properties. Cor Vasa 1992; 34(1): 82-87.

7. Widimský J, Kremer HJ, Jerie P et al Czech and Slovak Spirapril Intervention Study (CASSIS). A randomized, placebo, and active-controlled, double-blind multicentre trial in patients with congestive heart failure. Eur J Clin Pharmacol 1995; 49(1-2): 95-102.

\section{Zemřela Eva Klima, M.D.}

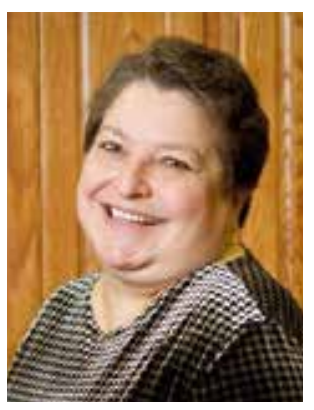

Nečekaná zpráva přišla z Houstonu v USA - ve věku 55 let nás opustila Eva Klima, dcera pana profesora Tomáše Klímy, zakladatele výměnného programu Texas-Czech Physician Exchange Program. Prof. Klíma prijijel do Československa ihned po listopadu roku 1989 a z vlastní iniciativy založil uvedený program, který umožnil 165 (!) českým lékařům 3měsíční stáž v Houstonu (Texas). Program umožnil všem seznámení $s$ medicínou řady oborů $v$ Texas Medical Center, což je jedno z největších medicínských center v USA. A byli to pravidelně kardiologové, kteří prošli stáží na Texas Heart Institute, po návratu mnoho z nich pak úspěšně pokračovalo $v$ akademické kariéře a stali se $z$ nich přednostové a primáři předních českých kardiologických pracovišt'. Byli to však i odborníci z řady dalších oborů - onkologie, hematologie, ORL, kardiochirurgové, chirurgové a další, kteří měli možnost poprvé poznávat medicínu v USA.

A byla to právě Eva Klima, M.D., se svou matkou MUDr. Marcelou Klímovou, které všem, kteří na stáž do Houstonu přiletěli, trvale pomáhaly s poznáváním nového pros- tředí, organizovaly setkání jak u Klímů doma, tak společenské akce s lékaři a s její rodinou. Eva byla lékařka narozená 3. 1. 1963 v Praze a do Houstonu príijela v roce 1969, když jí bylo 6 let. Tehdy prof. Tomáš Klíma definitivně Československo s rodinou opustil. Po ukončení studia na High School v Houstonu pak pokračovala na University of Texas a Baylor University v Houstonu, kde pak po promoci další 2 roky pracovala - nejprve v Houstonu, a potom v Dallasu v Texasu, až do nečekaného náhlého úmrtí 27. října 2018. Všichni, kdo měli možnost se s Evou poznat, cítili její milou vstř́ícnost a laskavost v době, kdy pro nás prostředí ve Spojených státech bylo zcela neznámé a nové. Zůstane proto $v$ našich vzpomínkách a vyjadřujeme hlubokou lítost nad jejím předčasným odchodem především Tomášovi Klímovi a celé jejich rodině.

Za výbor České kardiologické společnosti a všechny české lékaře, kteři prošli výměnným programem Michael Aschermann

\section{prof. MUDr. Michael Aschermann, DrSc. Aschermann@seznam.cz}

II. interní klinika - klinika kardiologie a angiologie 1. LF UK a VFN v Praze

www.cuni.cz 